Article

\title{
Implementing Nature Based Solutions in rural landscapes; Barriers experienced in the PHUSICOS project.
}

\author{
Anders Solheim 1*, Vittoria Capobianco ${ }^{1}$, Amy Oen ${ }^{1}$, Bjørn Kalsnes ${ }^{1}$, Turid Wullf-Knutsen ${ }^{2}$, \\ Mari Olsen ${ }^{2}$, Nicola Del Seppia ${ }^{3}$, Idoia Arauzo ${ }^{4}$, Eva Garcia Balaguer ${ }^{4}$, and James M. Strout ${ }^{1}$ \\ ${ }^{1}$ Norwegian Geotechnical Institute; ngi@ngi.no \\ ${ }^{2}$ Innlandet County Administration, Norway; innlandet@innlandetfylke.no \\ ${ }^{3}$ Autorità di Bacino del Fiume Serchio (ADBS), Italy; bacinoserchio@postacert.toscana.it \\ ${ }^{4}$ Consorcio de la Communauté de Travail des Pyrénées (CTP); contact(@)ctp.org \\ * Correspondence: anders.solheim@ngi.no; Tel.: +47-41653697
}

\begin{abstract}
Nature Based Solutions (NBS) are becoming increasingly important in both the EU and individual countries' political agendas, as a sustainable means to reduce the risk posed by hydrometeorological hazards. However, as the use of NBS is increasing, a number of barriers regarding their practical implementation also becomes apparent. A number of review studies have summarized and classified barriers, mainly in urban settings. PHUSICOS is a H2020 Innovation Action to demonstrate the use of NBS in rural and mountain landscapes. Large scale demonstrator case sites with several sub-projects are established in Italy, Norway and in the French and Spanish Pyrenees. The present paper describes the project's NBS measures, and their experienced barriers, some of which have resulted in full cancellation of the planned interventions. Many of the barriers experienced in rural settings have the same root causes as the ones described from urban areas, and the main barrier-creating mechanisms are institutional factors, resistance among stakeholders and technical and economic issues. The key element, however, is lack of knowledge about the ability of NBS to deliver a series of co-benefits in addition to their risk-reducing effects, and that long-term thinking is required to see the effect of many of these co-benefits.
\end{abstract}

Keywords: Nature-based solutions (NBS); Hydrometeorological hazards; PHUSICOS project; Implementation barriers; Flooding; Landslides; Avalanches; Rockfall; Europe

\section{Introduction}

Nature Based Solutions (NBS) is a collective term for solutions that are based on natural processes and ecosystems to solve different types of societal challenges. Of particular interest in the present study are adaptation strategies to reduce risk from hydro-meteorological hazards, such as landslides and floods. Although a wide range of definitions of NBS exists, as identified by [1]Ershad Sarabi et al. (2019), the European Commission's current definition is the presiding definition applied in the present study [2]; "Solutions that are inspired and supported by nature, which are costeffective, simultaneously provide environmental, social and economic benefits and help build resilience. Such solutions bring more, and more diverse, nature and natural features and processes into cities, landscapes and seascapes, through locally adapted, resource-efficient and systemic interventions". After the last report from the Intergovernmental Science-Policy Platform on Biodiversity and Ecosystem Services - IPBES, the following sentence has been added to the EC definition: "Nature-based solutions must therefore benefit biodiversity and support the delivery of a range of ecosystem services" (https://ec.europa.eu/info/research-and-innovation/researcharea/environment/nature-based-solutions_en). An important aspect of NBS therefore, is that they, in addition to reducing risk from natural hazards, also can deliver multiple other benefits [3] (Gomez 
Martin et al., 2020). These can be environmental, (e.g. enhancing biodiversity), social (e.g. creating green space, enhancing aesthetics and increase inhabitants' well-being), or economic (e.g. affecting property prices in a positive way, or creating green jobs in the region).

The present study is part of the project PHUSICOS ('According to nature', in Greek), funded by the European Commission under the Horizon 2020 program. The five-year project (May 2018 - April 2023) is an Innovation Action to demonstrate the effectiveness of NBSs and their ability to reduce the impacts from small, frequent events (extensive risks) in rural mountain landscapes. Nature-based solutions are cost-effective and sustainable measures inspired by nature that attenuate, and in some cases prevent, the impacts of natural hazard events and thereby the risks that affect the exposed regions. An important aspect of PHUSICOS is also the upscaling potential of the measures to be implemented.

The NBSs to be implemented and evaluated in PHUSICOS are based on modifying the vegetation cover and/or managing the excessive amount of surface water runoff during extreme events at demonstrator sites in rural landscapes throughout Europe. The successful implementation of such measures would not only reduce the risk to the local population but will also prevent the accumulated impacts of small events from becoming large-scale disasters (intensive risks) in densely populated urban areas downstream and far away from the source of hazard. Furthermore, many transportation routes, lifelines, and critical infrastructure that are essential for society pass through rural and mountainous areas and their functionality is threatened by landslides and floods triggered by hydro-meteorological events.

Research and evidence-based examples are still important to document that NBS are effective at larger scales, which is necessary information to enable changes in policies and practices. A first global systematic mapping of the effectiveness of nature-based interventions for addressing the impacts of climate change and hydrometeorological hazards was published by [4]. The authors concluded that there is a lack of robust, site-specific investigations of the effectiveness of interventions compared to traditional alternatives and such site-specific evidence is needed to support the political shift towards employing NBS. In addition to this lack of evidence, there are also several barriers, ranging from technical (i.e. design, planning) to of a practical character, that need to be considered when implementing NBS. Recent studies have also highlighted that main barriers hampering the proliferation of NBS in urban environments are mostly policy barriers, but that they are also contextand place-specific [5].

The aim of this paper is to present a selection of NBSs that are slated for implementation at European case study sites as well as to present and subsequently discuss barriers to the practical implementation of these NBS as experienced in PHUSICOS. The framing of this study in the perspective of barriers is intentional as it is experienced as a negative impact to the implementation of NBS. However, the focus on barriers is also meant to improve each barrier's respective enabling factor for planning future NBS interventions. This is summarized in the final section of the paper. Although problems are inevitable and new challenges will appear, the intention of sharing experiences and discussing how problems can be avoided is to reduce such barriers for NBS projects to come.

\section{PHUSICOS NBS interventions}

PHUSICOS includes three large scale demonstrator sites to demonstrate the functionality of NBS for reducing the risk from natural hazards. The large scale demonstrator sites are located in the valley of Gudbrandsdalen in Norway, in the Pyrenees of France and Spain, and in the Serchio River Basin in Italy (Table 1, Figure 1). The hazards comprise snow avalanches, landslides, rock fall, flooding and erosion. In addition, the Italian demonstrator site also deals with runoff from agricultural areas and therefore include spreading of pollutants. In addition, the project includes two smaller concept case sites; the Isar River in Munich [6], Germany, and the Kaunertal Valley in Austria [7]. The former is a 'retrogressive case' from which the PHUSICOS project intends to learn from their experiences, particularly regarding stakeholder involvement. The latter is an experimental case to use bacteriaenhanced growth to stabilize barren slopes, exposed in front of a rapidly retreating glacier. Further 
details of these two concept cases are not discussed in the paper, as they are less relevant regarding the discussion of barriers to implementation, being the second focus of this paper.

Table 1. Overview of NBS interventions in the PHUSICOS project. CC: Concept case sites. Status of mid-November 2020.

\begin{tabular}{|c|c|c|c|c|}
\hline Site & Proposal & Hazard & Type intervention & Status \\
\hline Gudbrandsdalen, Norway & G1: Jorekstad & Flooding & $\begin{array}{l}\text { Use of floodplain; receded } \\
\text { green barrier }\end{array}$ & $\begin{array}{c}\text { Approved, may be } \\
\text { cancelled }\end{array}$ \\
\hline Gudbrandsdalen, Norway & G2: Skurdalsåa & Flooding & Retention high in catchment & $\begin{array}{l}\text { Not yet formally } \\
\text { proposed }\end{array}$ \\
\hline Serchio River Basin, Italy & $\begin{array}{l}\text { SRB-A: Canals by Lake } \\
\text { Massaciuccoli }\end{array}$ & Erosion, run-off, pollution & Vegetated buffer strips & $\begin{array}{c}\text { Approved, } \\
\text { implemented }\end{array}$ \\
\hline Serchio River Basin, Italy & $\begin{array}{l}\text { SRB-B: Canals by Lake } \\
\text { Massaciuccoli }\end{array}$ & Erosion, run-off, pollution & Vegetated buffer strips & $\begin{array}{c}\text { Approved, } \\
\text { implemented }\end{array}$ \\
\hline Serchio River Basin, Italy & $\begin{array}{l}\text { SRB-C: Dam by Lake } \\
\text { Massaciuccoli }\end{array}$ & Erosion, run-off, pollution & Vegetated pond & Approved \\
\hline Serchio River Basin, Italy & SRB-D: NBS Lab & N/A & Educational & Approved \\
\hline Pyrenees, Spain & P1: Santa Elena & Erosion, rockfall, instability & Vegetated terraces & Approved \\
\hline Pyrenees, France & P2: Socques & Torrents & $\begin{array}{l}\text { Reduce torrent energy by } \\
\text { wooden check dams }\end{array}$ & Cancelled \\
\hline Pyrenees, France & P3: Artous te & Rockfall & $\begin{array}{l}\text { Wood structures to prevent } \\
\text { release and acceleration }\end{array}$ & Approved \\
\hline Pyrenees, France & P4: Bastan River & Flooding, torrents & $\begin{array}{c}\text { Change of river long } \& \\
\text { tranverse profile; allow more } \\
\text { room for floods }\end{array}$ & Cancelled \\
\hline Pyrenees, France & P5: Capet Forest & Snow avalanches & Afforestation in release area & $\begin{array}{l}\text { Approved, under } \\
\text { implementation }\end{array}$ \\
\hline CC - Isar River, Germany & Educational & Flooding & Flood plain restoration & Implmented \\
\hline CC - Kaunertal, Austria & Revegetation & Erosion, landslides & Microbe-assisted revegetation & $\begin{array}{c}\text { Under } \\
\text { implmentation }\end{array}$ \\
\hline
\end{tabular}




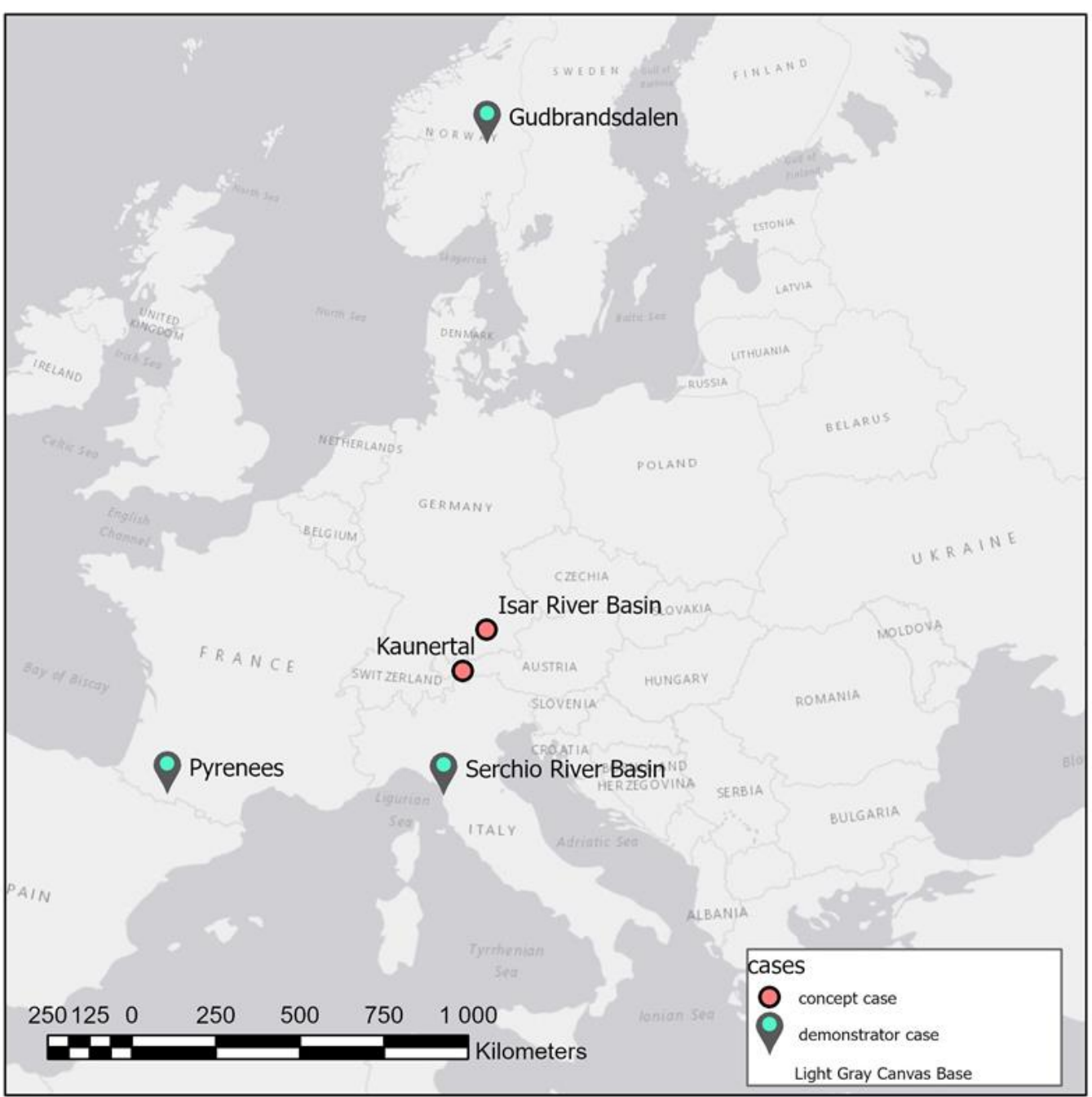

Figure 1. The three demonstrator sites (blue) and the two concept case sites (red) in PHUSICOS.

For each of the demonstrator case study sites, the NBS interventions that have been proposed by the site owners and subsequently approved by the PHUSICOS Steering Committee are briefly described below. The evaluation process assesses a range of parameters that reflect the requirements of NBS and include; effectiveness, co-benefits, stakeholder involvement as well as risk reduction which is a key parameter for PHUSICOS. Assessing potential negative impacts are also part of the evaluation (see [8]and [9] for details). Some selected comments and concerns from the Steering Committee are presented for the respective demonstrator sites, as these add to the discussion of barriers and to the 'lessons learned' from the PHUSICOS project.

\subsection{Gudbrandsdalen, Norway}

The first planned NBS intervention in the valley of Gudbrandsdalen is located on private land at Jorekstad in Lillehammer municipality in south eastern Norway(G1 in Figure 1) and comprises of a receded flood barrier along the lower reaches of the river Gausa, which is a tributary river to the main river of Gudbrandsdalslågen. During floods, the confluence area between the two rivers has repeatedly experienced problems [10]. This poses a threat to local infrastructure, farms and housing. Furthermore, eroded sediments from Gausa deposit in the confluence zone, changing river bottom configuration and thereby enhancing the flood problems. The measure is meant to provide area enough to reduce the energy of river Gausa before it enters the main river. At the same time agricultural land, farms and sports facilities are protected. The flood plain along Gausa has a riparian forest with several endangered species, and it is defined as an area of particular value for biodiversity 
by the Norwegian Environmental Directorate (https://kart.naturbase.no/), who also in fact recommend that the existing flood barrier along the river is moved to outside of the forest, to reestablish natural floodplain processes. The area consists of private land and is located in Lillehammer municipality.

Comments and concerns raised by the Steering Committee during the evaluation of the proposal comprised technical characteristics of the barrier, its height, shape, building material and aesthetics, as well as its protective capabilities details from hydraulic modelling. However, questions were also raised about the estimated cost, which seemed low, and on the prognosed time-line, which seemed short for such a large project, involving public procurement. Another question was regarding the level of detail in the participatory process and if the involved stakeholders had been sufficiently involved.

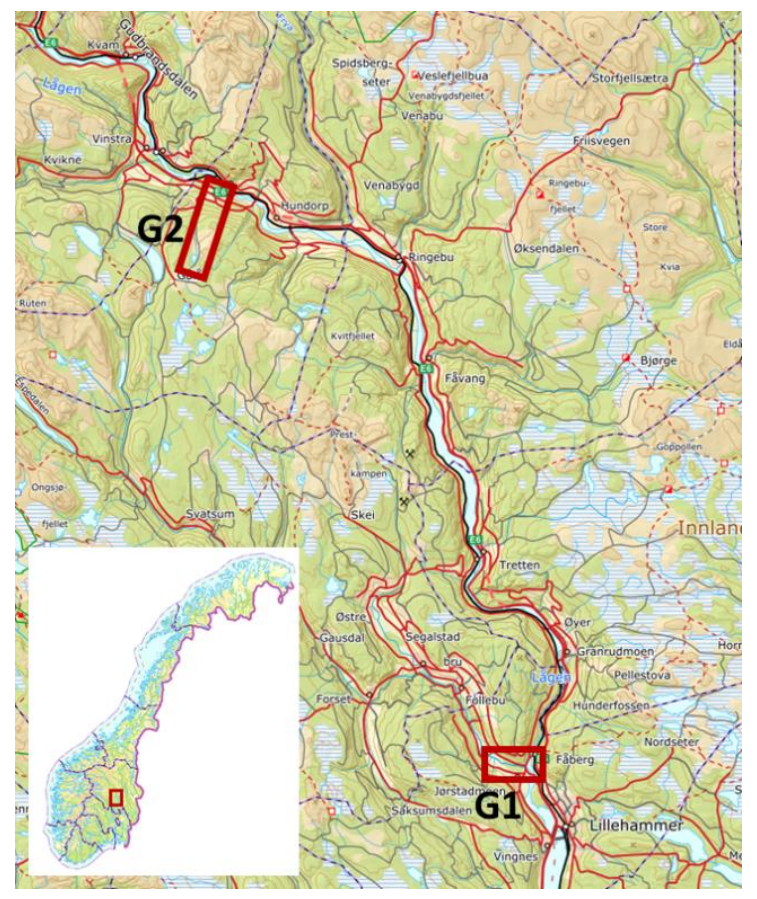

Figure 2. Location of the valley of Gudbrandsdalen, Norway. The city of Lillehammer is in the lower right corner. Locations are marked with red rectangles: G1: Jorekstad, G2: Skurdalsåa.

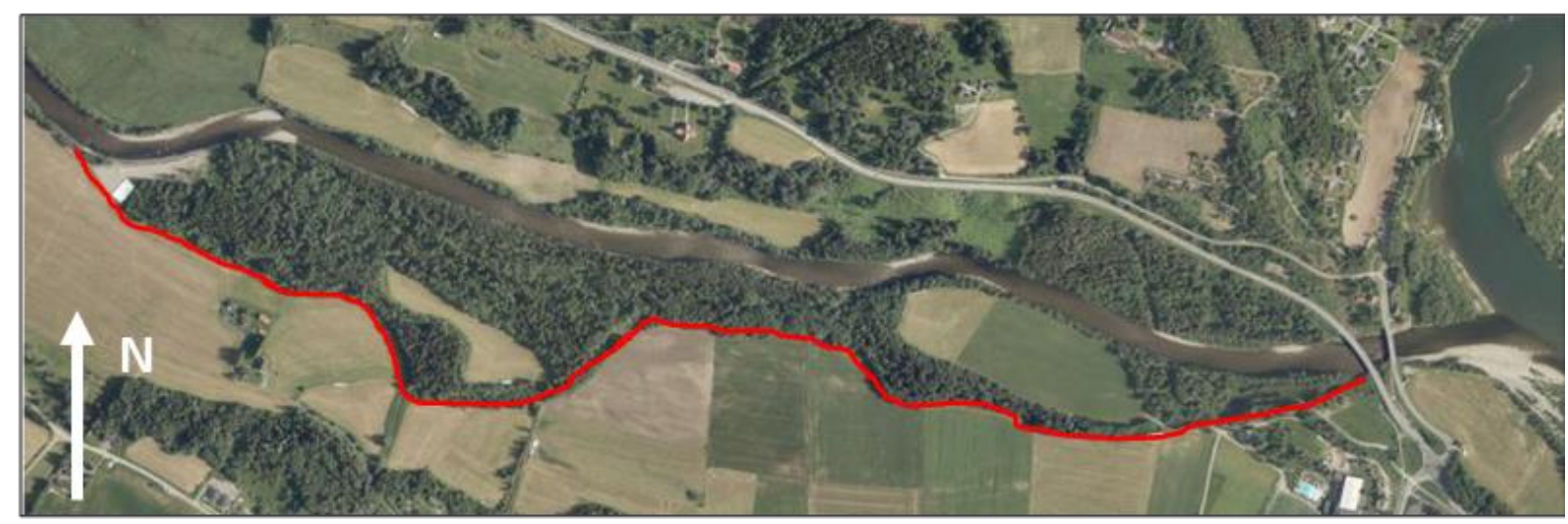

Figure 3. The lower reaches of river Gausa, where it enters the main river Gudbrandsdalslågen (far right). The proposed receded flood barrier (Location G1 in Figure 2) is marked with red. The original flood barrier follows the southern river bank. 
Another potential NBS intervention which is being considered for the Norwegian case study site, is the re-utilization of old dams for flood retention. This intervention is located in the Nord-Fron municipality further north in the valley and approximately $65 \mathrm{~km}$ from the Jorekstad site (G2 in Figure 2). The river Skurdalsåa is a relatively small tributary river to the main river Gudbrandsdalslågen in the middle part of the Gudbrandsdalen valley. The river responds rapidly to precipitation and infrastructure in the lower reaches have experienced severe flood

problems. Small lakes in the upper part of the catchment were built in the late part of the $19^{\text {th }}$ century to secure water for both consumption and for irrigation for the farms down in the valley. The measure to be proposed consists of re-establishing the function of the dam in one of these lakes, by adding 0,5-1,0 $\mathrm{m}$ to its height and securing proper spillways. Estimates indicate that the measure may delay flooding downstream by 1-2 days, enough to take necessary precautions.

This intervention has still not been formally proposed to the project's Steering Committee. However, the main concern for this measure is that it will have to be approved by the Norwegian authority for energy and water resources, with a possibility that this may trigger a set of actions and increased costs, with the potential consequence that the intervention is no longer feasible.

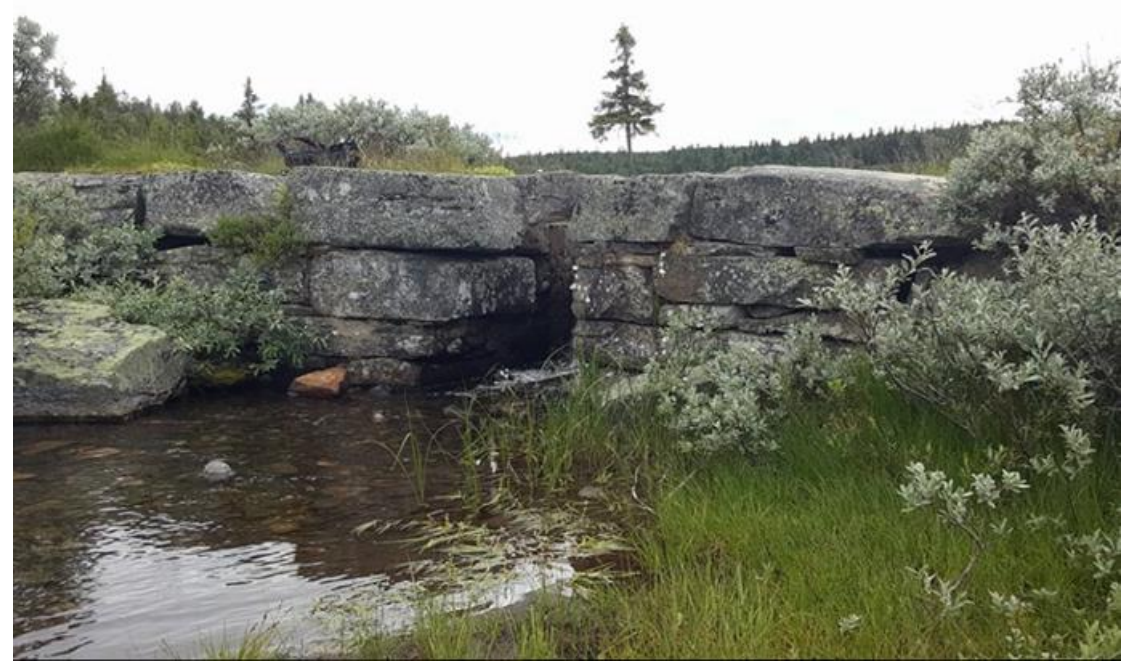

Figure 4 . The old (>100 years) dam in the catchment of river Skurdalsåa (Location G2 in Figure 2). The height of the dam will be increased by 0,5-1,0 m, but the appearance will remain. (Photo: 'Skurdalsåas venner')

\subsection{Serchio River Basin, Italy.}

The PHUSICOS NBS interventions to be implemented in Italy are located in private land near Lake Massaciuccoli in the region of Tuscany (Figure 5), and are focused on reducing runoff from farmland, with erosion and transport of sediments and pollutants to the aquatic environment [11]. The area is located south-east of Lake Massaciuccoli, a lake roughly at sea level, whereas the areas for the NBSs are 1-2 m below sea level, kept dry by a system of pumping stations. The lake is polluted from the surrounding farmland. It has connection to the ocean and during droughts, when the lake level is low, the locks cannot prevent influx of sea water, thus resulting in a very high salinity in the lake. The NBS interventions are intended to supplement an engineering solution to ensure a freshwater supply from the Serchio river during dry periods.

The measures to be implemented consist of a system of vegetated buffer strips along canals in two specified areas (Figure 5 and Figure 6), with different soil conditions. The main crops in these areas are corn, sunflower and wheat, and the species seeded in the grassy buffer strips consist of Festuca arundinacea, Lolium perennis, Trifolium repens and Trifolium subterraneum. These are all 
native species and are seeded in both buffer strip areas, but in somewhat different relative percentages, based on the soil conditions of the two areas. The water from these areas will be led through a sedimentation basin with Phragmites australis and Thypha latifolia for further sedimentation and filtering of pollutants, before the water eventually is lead through the pumping system and supplied to the lake. This intervention is currently in the planning stage. The most affected stakeholders are the local farmers, who are the landowners. The area receives a high number of tourists and is popular for hiking and biking activities.

In the evaluation process by the Steering Committee, in general the feasibility received high scores, as did the efficiency of the interventions. Main comments were related to the width of the buffer strips, the plants to be used, the relatively small size of the total area affected by the system of buffer strips and the sedimentation basin, the long-term maintenance and the level of risk reduction. However, concerns were also expressed regarding the needed agreement with the farmers to provide land, and the cost of potential compensation for land or even expropriation.

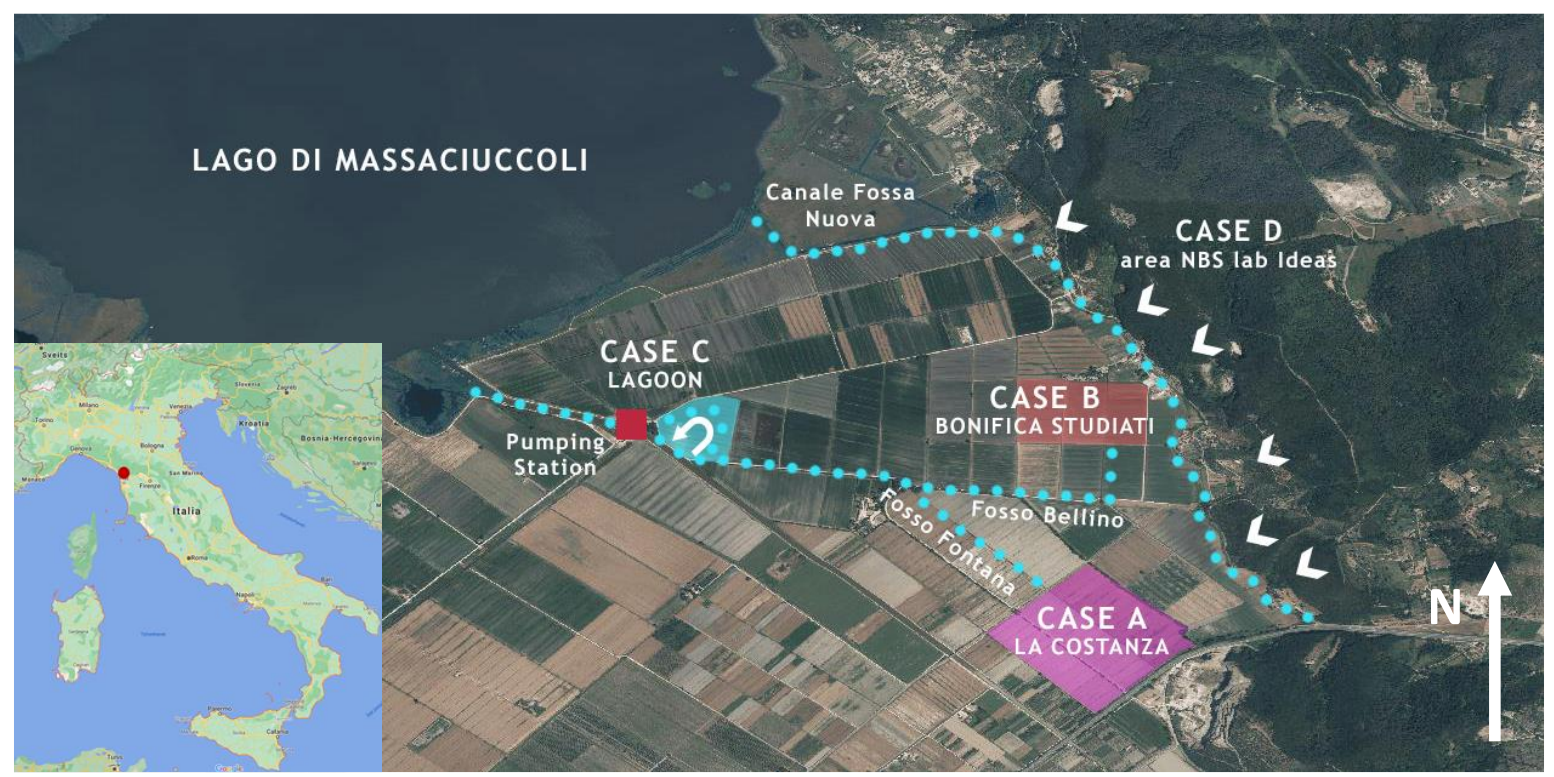

Figure 5. The area for NBS interventions by Lake Massaciuccoli. Buffer strips are being implemented in 'Case A' and 'Case B', whereas the retention and sedimentation dam is planned at the location of 'Case C'. 'Case D' denotes a suggested learning platform for NBS on the local and regional level. The slope where it is marked is prone to shallow landslides (white marks). (Illustration by ADBS)

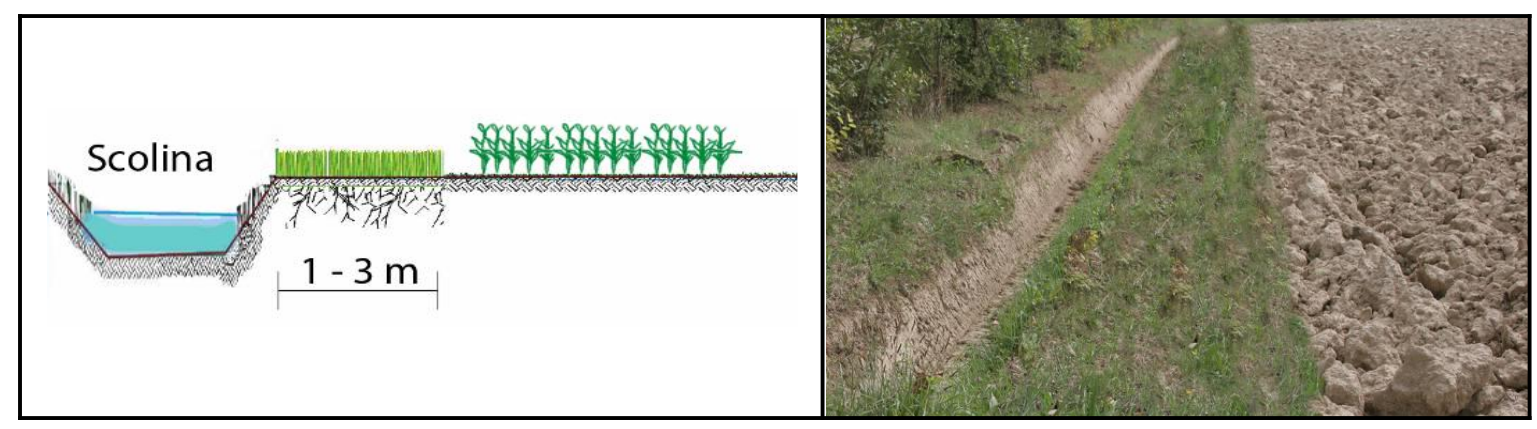

Figure 6. Sketch and example of the vegetated buffer strips being implemented along irrigation canals. (Illustration by ADBS) 


\subsection{The Pyrenees, France and Spain}

At present, five separate NBS interventions have been proposed and approved by the PHUSICOS Steering Committee in the French and Spanish Pyrenees. Three of the proposed interventions are located at sites along the same highly trafficked road between France and Spain, whereas the two other are located further to the east, in the Bastan Valley (Figure 7).The site owners, and thus the proponents for the interventions in the Pyrenees represent three different regional organizations.

The three sites (P1, P2 and P3 in Figure 7) along the trans-border road A-136 (Spanish side) / RD934 (French side) were all proposed by the 'European Grouping of Territorial Cooperation EGTC Space Portalet'.

The site at Santa Elena, Spain (P1 in Figure 7) is located in the municipality of Biescas. The road A-136 passes a large end moraine ridge and faces significant problems of erosion and resulting rockfall from the steep slope of the ridge (Figure 8). The location has been identified as a point of high risk in a consultant report, mainly because the of the limited visibility along the curved road, and the high potential for fallen rocks or debris on the road. The measure to be implemented consists of terracing and re-vegetation of the slope. This also includes solutions for drainage of the terraces, and careful selection of plants to ensure best stabilizing properties and not introducing alien species. The proposed measure will also require some engineered portions, and may classify as a hybrid solution. A similar type of measure at a much larger scale was completed in 1905, stabilizing a whole valley side north of the village of Biescas. This slope has not had problems since, and from a distance the measures are currently seen only as afforested hillside. The proposed measures at St. Elena are thus not new and innovative, but rather 're-discovering' techniques used in this region more than 100 years ago. Most comments from the Steering Committee during the evaluation process were concerning the technical details of the measure. It was considered feasible in the proposed time interval for implementation. 


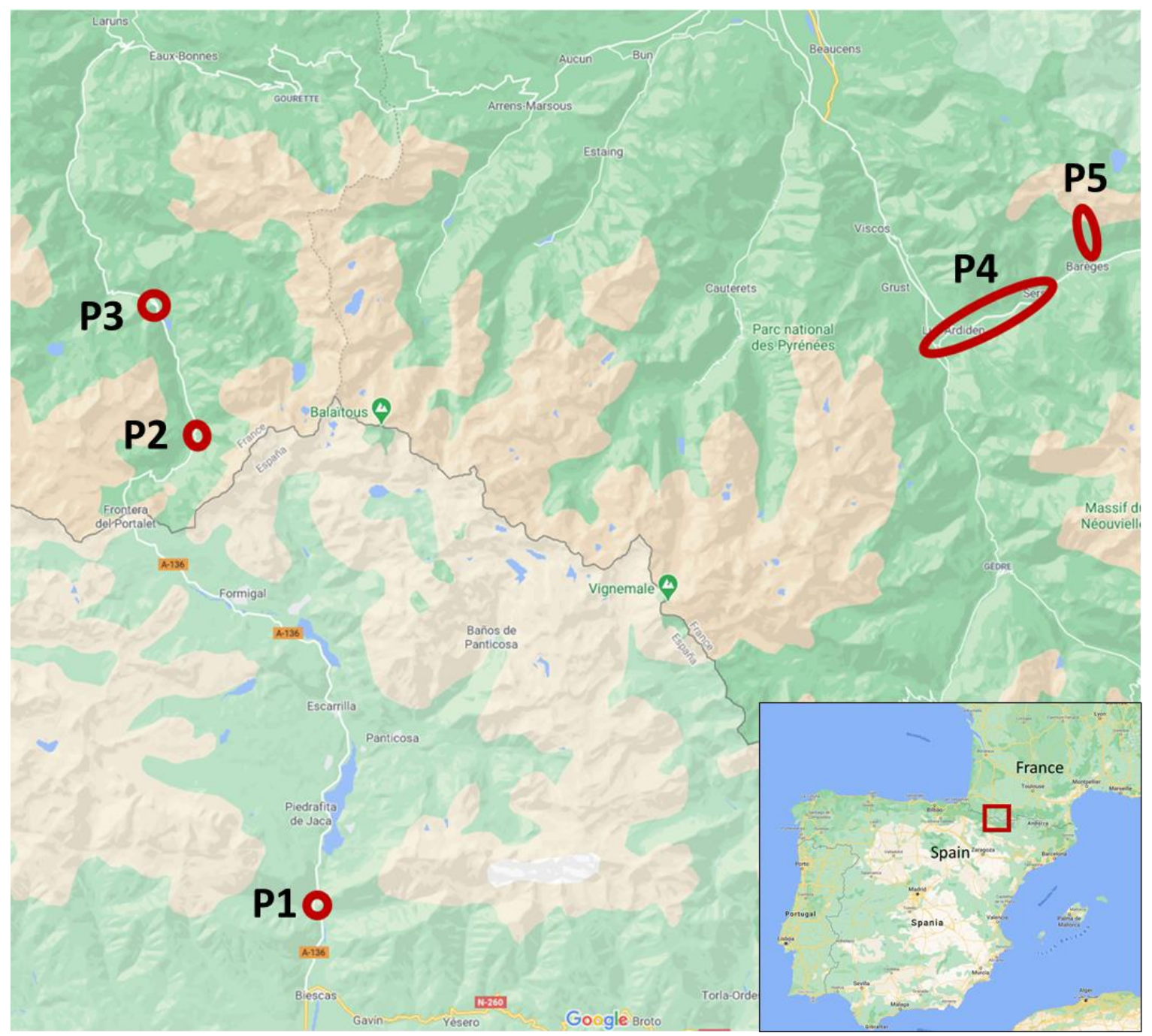

Figure 7. Location of the PHUSICOS sites in the Pyrenees. Sites for proposed and approved NBS interventions are marked P1-P5.

The second proposed NBS intervention along the trans-border road was at Socques, France, (P2 in Figure 7) where a torrent crosses and frequently affects the road RD-934. This intervention was, however cancelled for various reasons (below). The torrent flows through a ravine formed in thick deposits of easily erodible glacial sediments, which are regularly detached and transported downstream, clogging the drainage network, causing overflow and damage to the road. After a severe flooding and erosion event in 2013, about $10000 \mathrm{~m}^{3}$ of deposits had to be removed. The proposed measure was a system of check dams, to create a more balanced and stepped profile of the stream to reduce the energy of the water and favor controlled deposit of materials, for their subsequent removal. The check dams were to be built by local rocks and wood. The site is located in a National park, and this puts limits to the level of actions allowed. Partly due to restrictions caused by the national park status, and partly because this measure was considered too challenging and the solutions proposed would have a high probability of being insufficiently effective, the NBS interventions at Socques were cancelled before being evaluated by the Steering Committee.

Another proposed NBS intervention is under preparation further north along RD-934, near the hydropower dam of Artouste, in the municipality of LaRuns, France (P3 in Figure 7). The road descends in sharp turns from the height of the reservoir level to the base of the dam. In this area, within a forest predominantly of fir trees, several fragmented and unstable rock ledges, with partly detached rocks are sources of rock fall, which may hit the road with significant energy and cause damage to the road. A direct hit on a vehicle caused one fatality at the site in 2014. Preventive measures like fences near the 
road have proved insufficient as bouncing rocks have jumped over them. The NBS intervention to be implemented at Artouste consists of protective installations built of logs of local wood, close to the release areas, to either prevent release or to stop released blocks before they accelerate and reach high energy (Figure 8). These measures are to be combined with proper maintenance of the original forest in the slope, which also serve as barriers for smaller rocks. The area is on public land, owned by the LaRuns municipality, but is also within the Pyrenees National Park, which puts limits to the level of action in the area, the forest management, as well as the selection of plants. During the Steering Committee assessment of the proposal, most comments were related to the technical details of the measures. It was considered feasible, but some concerns were raised regarding the time for implementation, as well as the risk during the implementation / construction phase.

A NBS Proposal for the Bastan Valley, France, was proposed by the organization 'Pays de Lourdes et des Vallées des Gaves - PLVG', and consisted of two interventions in the municipalities of Sers, Betpouey, Viey, Viella and Sassis in the department of Hautes-Pyrénées (P4 in Figure 7). Both interventions were designed to prevent damage from torrents. The Bastan River is a tributary of the larger Gavernie River, and the first of the two interventions was to construct a step-and-pool profile along the Bastan River in a roughly $1 \mathrm{~km}$ stretch next to the village of Betpouey (P4, Figure 7). This was to be combined with strengthening and increasing the transitional zone along the river, which would allow more space for the river during floods but avoiding the severe erosion and damage previously experienced. The intention is further to upscale this at a later stage to other parts of the river, although this would not be part of the PHUSICOS project.

The second part of the Bastan Valley interventions was to remove a concrete structure, previously built in the confluence zone where the smaller Bastan river meets the bigger Gavernie River, near the village of Sassis. The structure forms a point into the river, which prevents natural flow and enhances the flooding problems. This structure was to be replaced by a green barrier, receded 10-12 $\mathrm{m}$ from the river and establishing a renewed riparian zone along the river.

Although the comments from the Steering Committee during the evaluation process were generally favourable regarding the feasibility of the proposed interventions and mainly requested further technical details, concerns were raised regarding the plan for implementation, which includes a significant stakeholder involvement. Contingency plans were requested. The proposed NBSs in the Bastan Valley have later been cancelled from the PHUSICOS project by the proponent, as there were uncertainties regarding cost, time for implementation and whether local politicians would reach agreement, in addition to a certain scepticism to the effectiveness of the solutions. Although these two interventions will not be carried out, the local stakeholder discussions are of interest for the forthcoming discussion on barriers to NBS. 

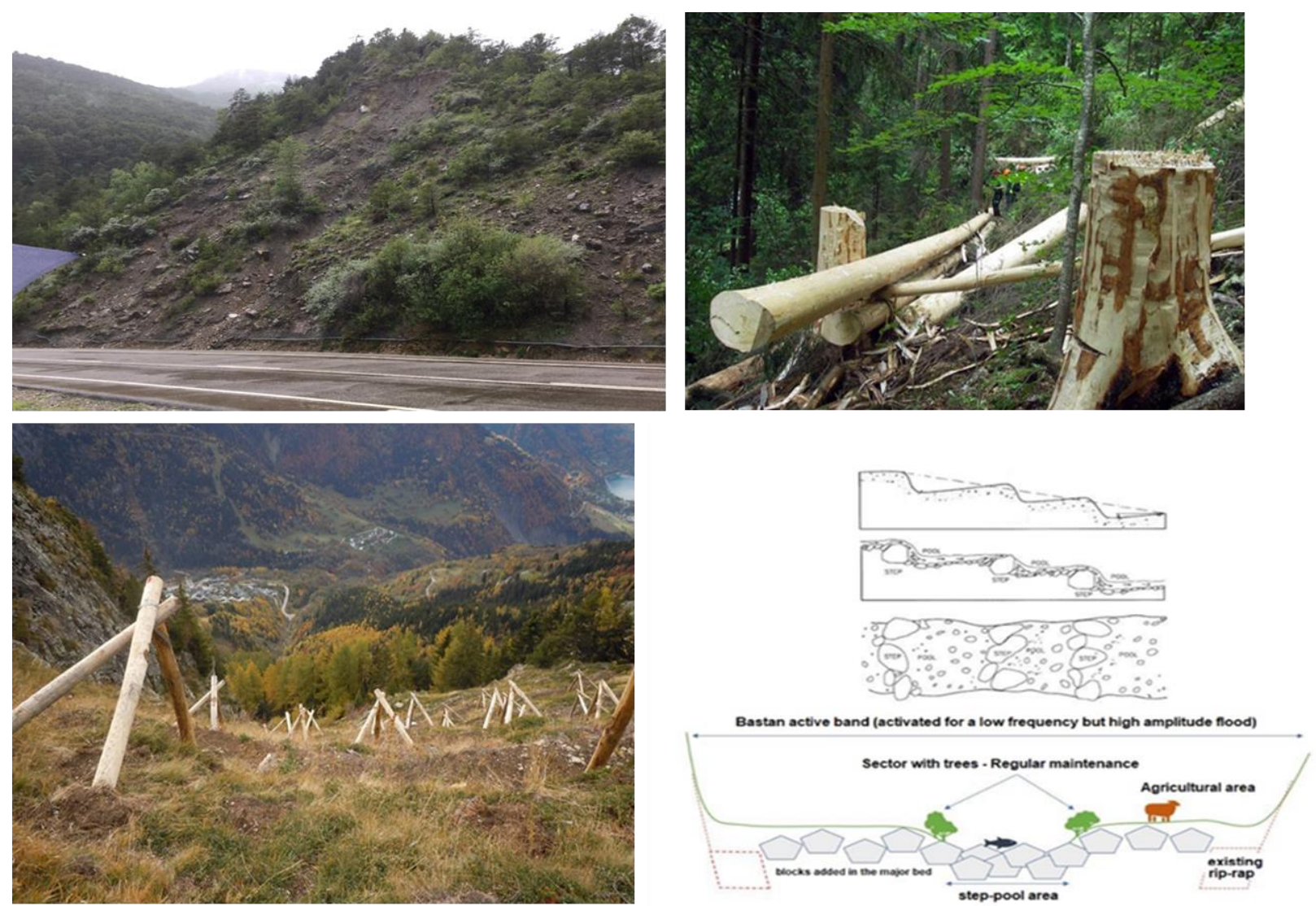

Figure 8. Sites and examples of Pyrenees NBS interventions. Upper left: The till slope at St. Elena, Spain (Photo: A.Solheim). Upper right: Example of wooden structures to be implemented near release areas for rockfall at Artouste, France (Photo: EGTC Space Portalet). Lower left: Wooden structures similar to those planned for the Capet site, to protect plants until they have a stabilizing effect (Photo: ONF). Lower right: longitudinal and transverse sections of the intended interventions in the Bastan River (From PLVG).

The fifth NBS sub-project in the Pyrenees, in the Forest of Capet, was proposed by the French Forest National Office (ONF) and the service of Mountain Terrain Restoration (RTM) in association with the French State represented by the Departmental Direction of the Territories (Hautes-Pyrénées) (P5, Figure 7). The proposed and approved intervention is located further up the Bastan Valley, in the north slope of the valley, facing the village of Baréges. Snow avalanches released from the upper slopes above Baréges pose a severe threat to the village and have also hit the village several times. Situations with high avalanche hazard often cause evacuations from parts of the village. The measure to be implemented consists of afforestation, with selected tree species built under protection of wooden tripods (Figure 8). Trees are carefully selected to suit the region and altitude. The tripods will protect the trees until they are high enough $(4-5 \mathrm{~m})$ to stabilize the snow pack, and during this initial growth period, the tripods will also have a stabilizing effect. There are several avalanche paths in the area, but the one in which the interventions are implemented was selected based on its topography and soil thickness. The evaluation comments from the Steering Committee were generally positive, with questions mostly related to details on the species select, growth rates, degree of protective capability, the planting techniques and maintenance. The proposed intervention was generally considered feasible within the time frame of the project.

\section{NBS implementation barriers}

In addition to the implementation of NBS, PHUSICOS is also exploring governance innovation, meaning that governance goes beyond government to involve a network of state and non-state actors (e.g., business, civil society, expert communities) in the process of deciding on and implementing 
NBS policy [12]. Despite the importance of successful NBS governance models to enable NBS implementation and upscaling, [12] found that research on the enablers of and opportunities for NBS implementation is sparse. Studies and reports are primarily focusing on urban NBS (e.g., [13]; [1]; [14]), their barriers (e.g., [15], [16]) or their potential for climate change adaptation (e.g., [17]; [18]). Additionally, governance criteria are underrepresented in NBS assessment frameworks [19], and little research has been conducted on the factors required for successful NBS design and implementation for DRR in rural and mountain areas [20].

[17] derived results from an inter- and transdisciplinary workshop with experts from research, municipalities, policy, and society. Among other aspects of NBS, they explored existing barriers and potential opportunities for increasing the scale and effectiveness of nature-based solution implementation in urban settings. They identified five main categories of barriers and presented these in a 'barrier circle' surrounded by opportunities (Figure 9).

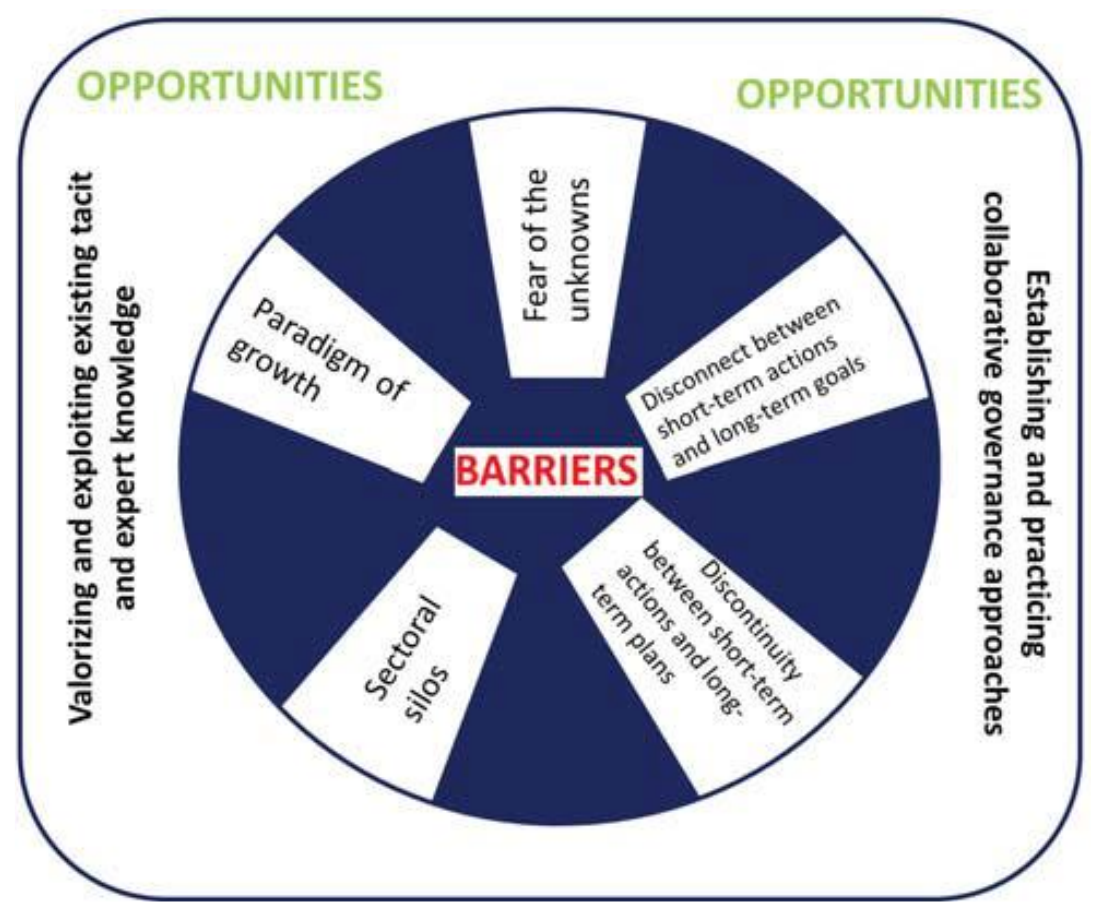

Figure 9. Combination of barrier circle and opportunities that facilitate action for NBNS in urban areas. [17]

[1] reviewed a number of published papers in their study on key enablers and barriers for NBS, also in urban settings. Through a selection procedure, they ended with 41 papers considered relevant. In addition to assessing the definitions of NBS, their main objectives, and main stakeholder groups, they concluded with a list of 6 main classes of barriers and 9 enablers. In a new paper, [16] increased and diversified this further into 15 classes of barriers, based on an analysis of published literature and expert interviews, ranked through a questionnaire and further analysed using Interpretive Structural Modelling (ISM).

The 15 classes of barriers of [16] are presented in Table 2 along with two additional classes of barriers that we have experienced in PHUSICOS. This classification is subsequently used for describing and classifying the barriers experienced in the first 2.5 years of the PHUSICOS project. The column headings in Table 2 denote the main type of barrier for each PHUSICOS example, but several of the challenges experienced in the project relate to more than one of [16]'s classes of barriers. These barriers have resulted in both delays of implementation, but also full cancellation of planned interventions. 
Table 2. Barriers for the implementation of NBS. No. 1-15 are from [16]. No. 16 and 17 are based on PHUSICOS experiences. Challenges may relate to more than one potential barrier. Bold text marks the barrier considered most important for each example.

\begin{tabular}{|c|c|c|c|}
\hline & Barriers: & PHUSICOS NBS sub-project & Comment \\
\hline 1 & $\begin{array}{l}\text { Lack of political will and long-term } \\
\text { comitment }\end{array}$ & Bastan Valley, Pyrenees, France; & Potential lack of will after local elections. \\
\hline 2 & $\begin{array}{l}\text { Lack of sense of urgency among } \\
\text { policymakers }\end{array}$ & Jorekstad, Gudbrandsdalen, Norway & \\
\hline 3 & Lack of public awareness and support & All sites & $\begin{array}{l}\text { Public awareness of the problem(s) but not of NBS } \\
\text { as a viable solution. }\end{array}$ \\
\hline 4 & Risk aversion and resistance to change & Bastan Valley, Pyrenees, France; & \\
\hline 5 & Silo mentality & & Not yet experienced in PHUSICOS \\
\hline 6 & $\begin{array}{l}\text { Misalignments between short-term } \\
\text { plans and long-term goals }\end{array}$ & Jorekstad, Gudbrandsdalen, Norway; & Jorekstad: tthe merger between counties. \\
\hline 7 & $\begin{array}{l}\text { Lack of supportive policy and legal } \\
\text { frameworks }\end{array}$ & Skurdalsåa, Gudbrandsdalen, Norway; & \\
\hline 8 & $\begin{array}{l}\text { Lack of design standards and guidelines } \\
\text { for maintenance and monitoring }\end{array}$ & & Not yet experienced in PHUSICOS \\
\hline 9 & $\begin{array}{l}\text { Lack of skilled knowledge brokers and } \\
\text { training programs }\end{array}$ & All sites & $\begin{array}{l}\text { Inadequate knowledge of NBS and, in particular } \\
\text { their co-benefits. }\end{array}$ \\
\hline 10 & $\begin{array}{l}\text { Functionality and performance } \\
\text { uncertainties }\end{array}$ & $\begin{array}{l}\text { Jorekstad, Gudbrandsdalen, Norway; } \\
\text { Socques, Pyrenees, France; } \\
\text { Bastan Valley, Pyrenees, France; }\end{array}$ & \\
\hline 11 & Percieved high cost & $\begin{array}{l}\text { Jorekstad, Gudbrandsdalen, Norway; } \\
\text { Bastan Valley, Pyrenees, France; }\end{array}$ & \\
\hline 12 & Lack of available financial resources & Jorekstad, Gudbrandsdalen, Norway; & \\
\hline 13 & Lack of financial incentives & Jorekstad, Gudbrandsdalen, Norway; & \\
\hline 14 & Property ownership complexities & $\begin{array}{l}\text { Jorekstad, Gudbrandsdalen, Norway; } \\
\text { Serchio River Basin (SRB), Italy; } \\
\text { Socques, Pyrenees, France; }\end{array}$ & $\begin{array}{l}\text { SRB: some discussion regarding the land needed } \\
\text { for the sedimentation basin. }\end{array}$ \\
\hline 15 & Space constraints. & & Not yet experienced in PHUSICOS \\
\hline 16 & Procurement & $\begin{array}{l}\text { Jorekstad, Gudbrandsdalen, Norway; } \\
\text { Bastan Valley, Pyrenees, France }\end{array}$ & \\
\hline 17 & Other factors & Gudbrandsdalen, Norway; & Income from gravel out-take after flood events. \\
\hline
\end{tabular}

\subsection{Lack of political will and long-term commitment}

In rural settings, municipalities are often small and local administrations have small personnel resources, where individuals may have multiple responsibilities. In such settings, co-creation and codesign in close dialogue with stakeholders is extremely important to avoid scepticism, which may seriously affect the project. It is also important to be aware of potential changes in the administration, e.g. in connection with upcoming elections, and to involve the entire political level in the NBS project, independent of political platform.

PHUSICOS experienced two examples where regional and local politics affected the decisionmaking process. In the Bastan Valley project, an additional factor, which eventually made the proponents call off the NBS plans, was the upcoming local elections and the prospect of changing the local government to one less in favour of NBS, and also with less knowledge of PHUSICOS and the planned interventions. Besides, it was of course unfortunate that the timing matched with elections, as sceptical stakeholders are also sceptical voters. Together, the two interventions along the Bastan river constituted the largest of the proposed NBS interventions in the Pyrenees, and it is important to learn from what caused the full cancellation of the plans. A closer involvement with the local and regional administration as well as other relevant stakeholders, such as farmers, over a longer time span prior to the planned implementation could have been one way to avoid the situation.

\subsection{Lack of sense of urgency among policymakers}

In Norway, a major reform, which included merging of counties, has affected the progress of PHUSICOS NBS implementations. The Oppland County was merged with the neighbouring 
Hedmark county from 2020. This resulted in a forced change of focus for PHUSICOS' original partner, Oppland County Administration, which now became part of the new Innlandet County Administration, with change of headquarters, and massive amounts of extra work related to the merger, also for the staff involved in the PHUSICOS project. Although this was not the main challenge for the implementation of the intervention at Jorekstad, the new priorities may have added to the delay in the progress for the approved case in Jorekstad, but also regarding new NBS proposals to PHUSICOS.

\subsection{Lack of supportive policy and legal frameworks}

In the Norwegian demonstrator case site Gudbrandsdalen, the measure to be proposed in the tributary river Skurdalsåa falls under the Norwegian regulations for dam classification. Norwegian dams are classified in 5 classes, $0-4$, with increasing requirements regarding safety. All classes except the lowest, 0 , require annual reviews including physical inspections. This will have an annual cost of NOK $50-100$ 000, which the dam owner, a small private association comprising the local land owners (farmers) along the river and the lake, cannot cover. Hence, if the re-vitalized dam cannot be classified as a 'Class 0 dam', the measure will not be carried through. There are hundreds of similar dams, built 100-200 years ago, in the catchments in Gudbrandsdalen and other Norwegian valleys, and therefore a successful project in Skurdalsåa would have a great potential for upscaling. Hence, regulations made for modern dams mainly for hydropower purposes, are not suited for regulating small adjustments, often involving improvements of the existing dam, which could be efficient flood retention without large new measures downstream.

\subsection{Lack of public awareness and support}

The scepticism experienced in PHUSICOS can for a large part be ascribed to lack of knowledge about NBS as effective mitigation measures, but perhaps most of all about the potential co-benefits of NBS. Co-benefits are an important evaluation criterion for the internal evaluation of interventions to be implemented in PHUSICOS. This type of scepticism is a key factor also for other classes of barriers, including land owner reluctance and local politics. Scepticism may also result from 'overselling' NBS as the only viable solution. Accepting that NBS may not be the right solution for all climate induced hazards, and that both traditional solutions and hybrid solutions may be the right solution in several cases, is important. In PHUSICOS, we have experienced scepticism as a component in several of the challenges we have faced, and even if it may not be the single key factor, which makes the intervention be delayed or cancelled, it certainly affects the processes towards implementation. Examples comprise land owners at the Norwegian site at Jorekstad, as well as both land owners, administration and politicians in the case of the planned Bastan Valley interventions.

\subsection{Property ownership complexities}

PHUSICOS' NBS interventions are planned on both public and private land. This leads to both challenges and possibilities, and examples prove the importance of enthusiasm and sense of ownership from the land owners' side, whether these are private or public. It also demonstrates the importance of knowledge. All three of these aspects; enthusiasm, sense of ownership and knowledge, can be improved through close stakeholder involvement from the early stage, through co-creation and co-design, often also co-defining and agreement of the problems to solve.

In the Serchio River Basin demonstrator case site by Lake Massaciuccoli, the 'site owner', ADBS has had close interaction with farmers and their organizations. This has resulted in availability of necessary land for the two sets of vegetated buffer strips along the irrigation canals. The land owners also offer personnel and machinery for the implementation of the measures. Furthermore, ADBS 
receives increased interest from other farmers to have similar measures implemented on their land. The projects therefore see a great potential for upscaling in this area.

At the Norwegian demonstrator site in the Gudbrandsdalen Valley, the land to be affected by the receded flood barrier at Jorekstad is private. Initially, the attitude among the affected farmers was generally positive. However, the public hearing of the new land use plan for the area, resulted in numerous comments and requirements. Many of these are relevant and useful comments to the technical solutions and its effect, but others are based on economic motives, and include for example compensation claims. Yet others are caused by lack of knowledge on NBS and scepticism on whether this will reduce the flood risk as well as, or better than traditional 'grey' measures. Lack of knowledge around NBS' co-benefits is particularly pertinent.

In the demonstrator case site, the Pyrenees, the approved NBS interventions include both private and public land. In the cancelled case in the Bastan Valley, scepticism regarding the effectiveness of the NBS interventions from land owners applied as it did in the Norwegian case at Jorekstad. This added yet another reason that the interventions were called off. However, another challenge was also introduced in the Pyrenees, as some of the publicly owned areas are national parks. The proposed and approved measures at Socques were called off partly because of doubt regarding their effectiveness in reducing the risk from torrents, but also because their location in a national park placed serious limitations to the level of interventions allowed. The forest of Capet, where the NBS is afforestation to prevent release of snow avalanches, is also part of a national park. This has put limitations on the implementation activities, such as helicopter traffic, use of heavy machinery. However, this has been solved and the implementation is well underway, keeping within the allowed level of activities. For the interventions in the Capet Forest, the attitude among all stakeholders, from the inhabitants to the political level, was generally positive, as existing measures, which also were more environmentally intrusive, did not reduce the risk sufficiently.

\subsection{Time needed for public procurement}

Most European countries align with general rules for public procurement within the EU. However, some countries have additional regulations including threshold values and types of activities. Norway, as non-EU member, has its own regulations regarding public procurement. Common for all is that the procurement documents need to be carefully prepared and the protocol must be followed. The procurement process itself necessarily takes time. For example, in Norway certain time intervals must be given from the call for tenders to the deadline for bids. Then time for evaluation of bids and announcing the winner, followed by usually two weeks' time for potential complaints. The whole process will take at least 2-3 months if all go smoothly. In the case of complaints, the whole process is further delayed, and if the complaint is based on formal errors in the tender documents or in the selection process, the procurement process must start over again.

At the Norwegian demonstrator site Gudbrandsdalen, one of the bidders of the competition for detailed design of the receded flood barrier at Jorekstad complained after the winning bidder had been selected. The competition did not have to be re-announced, but the process of handling the complaint according to the protocol took another 2 months, although the final result of the competition did not change. Such delays in rural mountainous areas, which is the case for PHUSICOS, are particularly critical as the seasons for implementing measures on site may be short. Delays of 2-4 months may in fact, cause a one year delay because one may have to wait until the following season to begin construction activities. This is certainly also the case in the demonstrator sites in the Pyrenees, where the season for physical work on site is short, and it is essential to time the procurement process right, to avoid delays of up to one year.

One of the reasons for the cancellation of the challenges faced in the Bastan Valley in the Pyrenees, was the expected time delay from call for tenders to implementation. In the case of EU funded projects, such as PHUSICOS, costs registered after the formal project's end cannot be claimed. Therefore, even with a one year extension of the project, until April 2023, the proponents of the measures against flooding in the Bastan Valley, concluded that the probability of long delays was too 
large. This, in addition to local politics and stakeholder skepticism resulted in the cancellation of this NBS implementation

\subsection{Other factors}

Most barriers experienced in the PHUSICOS project are covered by the main classes described above. However economic reasons may also be a cause for resistance, and not only related to claims for loss of arable land. In the valley of Gudbrandsdalen, the catchment of the river Gudbrandsdalslågen and its tributary rivers drain large areas of glacial tills. This results in severe erosion, which is a problem in itself, but which also leads to transport and deposition of large amounts of sand and gravel. Gravel out-take after flooding events is therefore an important additional income for land owners along some of the rivers, and this may cause reluctance to implement flood reducing measures of any type.

\section{Discussion}

A number of potential barriers for the implementation of NBS has been identified in the literature. The large majority of these are based on urban settings, but many of the same barriers are relevant also for rural areas, as shown by the experiences of the present project.

In PHUSICOS, we have grouped the challenges experienced so far in accordance with the barrier classes defined by [16], and added one more specific class, 'Procurement', and one collective 'other factors' (Table 2). However, we experience that several of the challenges relate to more than one cause, and in Table 2, each PHUSICOS example are connected to more than one of the barriers of [16]. For instance, the cancellation of the proposed and approved measures to reduce the risk from flooding in the Bastan Valley, is ascribed mainly to lack of political will and long-term commitment, but additional factors also include lack of public support, risk aversion and resistance to change (more trust in well-known traditional solutions, even if they have failed previously), uncertainty of NBS functionality and perceived high cost. Similarly, the challenges for the Jorekstad site in Norway is mainly suffering from lack of financial resources, but at the same time we see few financial incentives in the municipal, regional or even national legislations. The public hearings connected to the new land use plan have also revealed uncertainties and scepticism to the functionality and performance of NBS. The larger scale national political discussion of reducing the number of counties in Norway through mergers, have also affected the progress of the process towards implementation of the proposed NBS.

A common issue, which may be hidden behind many of the above defined barriers, is scepticism caused by lack of knowledge about NBS and, in particular their co-benefits. This knowledge gap comprises all relevant actors and stakeholders, authorities, land owners, politicians, contractors in the building and construction industry. To see the full effect of co-benefits requires long-term planning and thinking. Furthermore, long-term monitoring of all effects and of affected people's perception of the measures is needed, which may improve when co-benefits become apparent. On the political level, election periods of typically 4 years also put a constraint on the long-term planning. To see the full effect of co-benefits may require longer time than this.

To overcome scepticism, sharing of experience and knowledge between groups with different expertise and experiences is important. This was also identified as an important activity by [21] in their paper on strategies for overcoming NBS barriers. The effect of knowledge sharing from different groups was emphasized as very important, in particular in the context of NBS, where institutional knowledge is generally very limited [21]. Their study was based on urban settings in Swedish cities, but the findings are also applicable to the rural settings, as seen by the experiences of the PHUSICOS project.

Furthermore, avoiding 'over-selling' NBS as the only viable solution to reduce risk from hydrometeorological hazards may also help overcome scepticism. A significant portion of NBS interventions require engineering to various degrees and may therefore also be classifies as hybrid 
solutions. [3] in their classification scheme for NBS, divided this in three types, from Type 1 with low human intervention, to Type 3, with high human intervention. The receded flood barrier at Jorekstad, Norway, would for instance classify as Type 3, whereas the buffer strips in the Italian case would be a Type 2 intervention. An important point of [3] is also that the vast majority of NBS require ongoing maintenance. The acceptance of these facts when advocating NBS to policymakers and other stakeholders may also be a means to meet sceptics and increase knowledge.

The issue of supportive policy and legal frameworks affects the planned measures in Skurdalsåa, Norway negatively as it until now has created uncertainty around whether the measure can be carried through to implementation. In Norway, on the other hand, the Norwegian Environment Agency has issued regulations, which require NBS to be considered when mitigation measures for natural hazards are being planned. Furthermore, if NBS is not chosen, this has to be justified [22]. This is clearly a step in the right direction and will, if it is getting known and being used, form an incentive for change towards NBS.

The challenges regarding procurement experienced by PHUSICOS are somewhat different from the main challenges described for urban areas by [23]. Based on nine case studies from European cities, they point out a number of challenges experienced and solved by the procurers. The issue of time for the procurement process is touched upon, but most of the challenges relate to difficulties finding enough skilled and experienced bidders, as well as obtaining enough citizen involvement, enthusiasm and ownership to the solutions. These issues align with several of the barriers identified by [1] and [16], such as barriers 3 and 8 in Table 2 . An approach that could help to overcome procurement process barriers can be found in the concept of 'innovative partnerships' used in a case study from Fredriksberg, Denmark [23]. This is a model, which may trigger innovation and also speed up the total procurement process. It consists of a competitive phase, where suitable partners are selected, followed by an $R \& D$ phase where the innovative solutions are developed in collaboration with the contracting authority. This is again followed by the commercial phase, where the selected partner provides the final product. This means that the new solutions can be purchased directly at the end of the process, without the need for further procurement to upscale the preferred solution.

The analyses of [16] of NBS in urban settings concluded that political, institutional and knowledge-related barriers are the most dominant barriers to successful NBS implementation. We see the barriers experienced in the PHUSICOS project, in rural settings, result from the same main mechanisms, including institutional factors, resistance among stakeholders and technical and economic issues.

Success stories, which can be used to promote NBS against landslides and flooding in rural areas are generally scarce, but despite the challenges emphasized in this paper, we are confident that the PHUSICOS project will create success stories. The afforestation interventions in the Capet Forest is going according to plans, as are the interventions in Italy, where an increasing number of farmers around Lake Massaciuccoli are showing interest in the measures. Despite delays, as described above, NBS activities will also be implemented during the course of the project and will be monitored for both benefits and co-benefits through the project period and after, following a comprehensive evaluation framework developed in the project [24].

\section{Conclusions; Lessons learned}

A common denominator for the experienced and reported barriers to NBS implementation is lack of knowledge leading to scepticism. In particular the advantage NBS have over other adaptation strategies in their ability to deliver multiple benefits are too poorly known among all relevant stakeholder groups. Based on the challenges experienced in the PHUSICOS project, find below a summary of a list of key elements, which may help overcome NBS barriers:

- Involve all relevant stakeholder groups at an early stage. This may even include co-defining the problem that requires mitigation. Private and public land owners are among the most important groups, as is the local and regional administrative and political level. 
- Spend time and resources on explaining the co-benefits. If possible, try to quantify the real value of the co-benefits over time.

- Use relevant success stories in the dialogue with the stakeholders. In PHUSICOS, the Isar River case is presently such a success story (e.g. [25]).

- NBS should not be 'over-sold'. To acknowledge that both traditional, 'grey' solutions as well as various types of hybrid solutions are viable solutions in many cases may also be a means to meet scepticism.

- Educational material and information meetings with stakeholders can fill knowledge gaps. Construction companies should be included, as they are most often involved in the practical construction of NBS.

- Time for proper procurement must be allowed in the planning. Innovative procurement, like the example from Denmark [23], should be considered if possible.

- Carefully investigate all rules and regulations which apply and what approvals are required. Application procedures may take time and delay the project significantly. Protected areas like national parks may be particularly challenging.

- A comprehensive quality assurance of all suggested measures by a broad range of experts is important. In PHUSICOS the Steering Committee formed the QA body, and a more careful following-up of comments, concerns and recommendations from the evaluation process might have helped lowering some of the barriers.

Author Contributions: Conceptualization, Solheim, Oen, Capobianco and Kalsnes; methodology, Solheim, Oen, Capobianco and Kalsnes; validation, Solheim, Oen, Capobianco and Kalsnes; formal analysis, Solheim; investigation, Solheim, Oen, Capobianco and Kalsnes, Wullf-Knutsen, Olsen, del Seppia, Arauzo and Balanguer; resources, Solheim, Oen, Capobianco and Kalsnes, Wullf-Knutsen, Olsen, del Seppia, Arauzo and Balanguer; writing-original draft preparation, Solheim; writing-review and editing, Solheim, Oen, Capobianco and Kalsnes ; project administration, Oen; funding acquisition, Oen and Kalsnes All authors have read and agreed to the published version of the manuscript.",

Funding: Please add: The PHUSICOS project has received funding from the European Union's Horizon 2020 research and innovation programme under grant agreement No. 776681.

Acknowledgments: Information on the three demonstrator case sites are provided from the Innlandet County Administration, Norway, the Autorità di Bacino del Fiume Serchio (ADBS), Italy and the Consorcio de la Communauté de Travail des Pyrénées (CTP), Spain and France

Conflicts of Interest: The authors declare no conflict of interest. The funders had no role in the design of the study; in the collection, analyses, or interpretation of data; in the writing of the manuscript, or in the decision to publish the results. 


\section{Appendix B}

All appendix sections must be cited in the main text. In the appendixes, Figures, Tables, etc. should be labeled starting with 'A', e.g., Figure A1, Figure A2, etc.

\section{References}

1. Ershad Sarabi, S.; Han, Q.; Romme, A.G.L.; de Vries, B. \& Wendling, L. Key enablers and barriers to the uptake and implementation of Nature-based solutions in urban settings: A review. Resources 2019,

8, 121; doi:10.3390/resources8030121

2. European Commission. Towards an EU Research and Innovation Policy Agenda for Nature-Based Solutions \& Re-Naturing Cities: Final Report of the Horizon 2020 Expert Group on Nature-Based Solutions and Re-Naturing Cities 2015, European Commission: Brussels, Belgium.

3. Gómez Martin, E.; Mánez Costa, M. \& Schwerdtner Ménez, K. An operationalized classification of Nature Based Solutions for water-related hazards: From theory to practice. Ecological Economics 2020, 167 (2020) 106460.

4. Chausson, A.; Turner, B.; Seddon, D.; Chabaneix, N.; Girardin, C. A.; Kapos, V. \& Seddon, N. Mapping the effectiveness of nature-based solutions for climate change adaptation. Global Change Biology 2020, 26(11), 6134-6155.

5. Bernardi, A.; Enzi, S.; Mesimaki, M.; Lehvavirta, S.; Jurik, J.; Kolokotsa, D.; Gobakis K., van Rompaey, S.; Goni, E.; Mink, E.; Sansoglou, P.; Porter, J.; Lemaitre, F.; Streck, A. \& Elgar, H. Barriers landscape and decision making hierarchy for the sustainable urbanisation in cities via NBS. From thinknature handbook (chapter 7) (Deliverable 5.1). 2019 https://platform.thinknature.eu/system/files/thinknature handbook final print 0.pdf

6. Pugliese, F.; Caroppi, G.; Zingraff-Hamed, A.; Lupp, G. \& Giugni, M. Nature-Based Solutions (NBSs) Application for Hydro-Environment Enhancement. A Case Study of the Isar River (DE). In Environmental Sciences Proceedings 2020. 2(1), 30.

7. Haselberger, S.; Ohler, L-M.; Junker, R.; Otto, J.-C.; Glade, T. \& Kraushaar, S. Quantification of biogeomorphic interactions between small-scale sediment transport and primary vegetation succession in the Gepatschferner glacier foreland, Austria. Submitted 2020 to Earth Surface Processes and Landforms.

8. Solheim, A. Procedures for distribution of funds and tenders. H2020-PHUSICOS Deliverable D2.1, 2018, 46pp. https://phusicos.eu/wp-content/uploads/2019/01/D2_1_Procedures_Rev1_Procedures-fordistribution-of-funds-and-tenders final.pdf

9. Solheim, A. \& Capobianco, V. Overview of submitted and approved NBSs for implementation during months 1-14. H2020-PHUSICOS Deliverable D2.2, 2019, 30pp. https://phusicos.eu/wpcontent/uploads/2019/01/D2_2_Rev-1_Overview-of-submitted-and-approved-NBSs-months-114_final.pdf

10. Oppland County Administration. Regional master plan for the Gudbrandsdalslågen and its tributaries; Measures to reduce damage from flooding and landslides. 2018, Open report, 95pp.

11. Silvestri, N.; Pistocchi, C.; \& Antichi, D. Soil and Nutrient Losses in a Flat Land-Reclamation District of Central Italy. Land degradation $\mathcal{E}$ development, 2017, 28(2), 638-647.

12. Martin, J.; Bayer, J.; Liu, W; Scolobig, A. \& Balsiger, J. NBS in-depth case study analysis of the characteristics of successful governance models. PHUSICOS Deliverable D5.1, 2019 (https://phusicos.eu/wp-content/uploads/2020/10/D5 1 NBS-in-depth-case-study-analysis Final.pdf) 
13. Raymond, C.M.; Frantzeskaki, N.; Kabisch, N.; Berry, P., et al. A framework for assessing and implementing the co-benefits of nature-based solutions in urban areas. Environmental Science \& Policy 2017 77, 15-24.

14. Somarakis, G.; Stagakis, S. \& Chrysoulakis, N. Thinknature Nature-Based Solutions Handbook. ThinkNature project funded by the EU Horizon 2020 research and innovation programme 2019 [Online]. Available from: https://platform.think-nature.eu/content/thinknature-handbook.

15. Schmalzbauer, A. Barriers and success factors for effectively cocreating nature-based solutions for urban regeneration. Deliverable 1.1.1, CLEVER Cities 2018, H2020 grant no. 776604.

16. Ershad Sarabi, S.; Han Q.; Romme, A.G.L.; de Vries, B.; Valkenburg, R. \& den Ouden, E. Uptake and implementation of Nature-Based Solutions: An analysis of barriers using Interpretitive Structural Modeling. J. Environmental Management 2020, 270, 110749.

17. Kabisch, N.; Korn, H.; J., S. \& A., B. Nature-Based Solutions to Climate Change Adaptation in Urban Areas. [Online]. Springer. 2017, Available from: doi:10.1007/978-3-319-56091-5.

18. Kuban, B.; Demir, E.; Emir, K. \& Tabanoğlu, O. D1.5: Barriers and Boundaries Identification. 2018

19. Sekulova, F. \& Anguelovski, I. The Governance and Politics of Nature-Based Solutions. [Online]. 2017 Available from:

https://naturvation.eu/sites/default/files/news/files/naturvation the governance and politics of nat ure-based solutions.pdf.

20. Accastello, C.; Blanc, S.; Brun, F.; Accastello, C., et al. A Framework for the Integration of NatureBased Solutions into Environmental Risk Management Strategies. Sustainability 2019. [Online] 11 (2), 489. Available from: doi:10.3390/su11020489 [Accessed: 1 February 2019].

21. Wamsler, C.; Wickenberg, B.; Hanson, H.; Olsson, J.A.; Stålhammar, S.; Björn, H.; Falck, H.; Gerell, D.; Oskarsson, T.; Simonsson, E.; Torffvit, F. \& Zelmerlow, F. Environmental and climate policy integration: Targeted strategies for overcoming barriers to nature-based solutions and climate change adaptation. Journal of Cleaner Production 2020, 247 (2020) 119154.

22. Norwegian Environmental Agency, 2018

https://www.miljodirektoratet.no/myndigheter/klimaarbeid/klimatilpasning/veiledning-til-statligeplanretningslinjer-for-klimatilpasning/vurdere-naturbaserte-losninger/ (in Norwegian)

23. Maciulytè, E. \& Durieux, E. Public procurement of nature-based solutions. Addressing barriers to procurement of urban NBS: Case studies and recommendations. European Commission, DirectorateGeneral for Research and Innovation 2020, ISBN 978-92-76-21601-8, 45pp.

24. Autuori, S.; Caroppi, G.; De Paola, F.; Giugni, F.; Pugliese, F.; Stanganelli, M. \& Urciuoli, G. Comprehensive Framework for NBS Assessment. PHUSICOS Deliverable D4.1. 2019, https://phusicos.eu/wpcontent/uploads/2019/05/D4.1_Task4.1_UNINA_14052019_Final_withAppendicies.pdf

25. Mahida, N. Great (un) expectations: the Isar-Plan in Munich In: Management SOFW, (ed) European River Restoration Conference. European Center for River Restoration, Vienna, Austria, 2013 